\title{
Tactics of Forming a System of Financial Indicators of the Enterprises in the Operational Aspects
}

\author{
Ajupov A.A. ${ }^{a}$ \\ Kurilova A.A.b \\ Evstigneeva O.A.c
}

aKazan Federal University, Institute of Management, Economics and Finance, Kazan, 420008, Russia

bcTogliatti State University, Togliatti, 445667, Russia

Email:aakurilova@yandex.ru

\section{Doi:10.5901/mjss.2015.v6n1s3p55}

Abstract

The article contains a number of theoretical and methodological developments and practical recommendations for the tactics of forming financial indicators and to ensure their sustainable basis the financial condition, proposed modeling scheme of financial indicators and indicators with the recommended performance standards for the level of the financial condition of the operational aspect.

Keywords: enterprise, financial condition, financial performance, planning; analysis, control, accounts receivable, debtors, accounts payable, cash, revenue, cost, inflows and outflows of cash, profit.

\section{Introduction}

In the context of mass insolvency of enterprises and the practical application of many of these bankruptcy proceedings objective and accurate assessment of their financial condition is paramount.

The research of selected topics determined by the need for more research in the field of modeling parameters reflecting the level of the financial condition of the enterprise in the market economy from the perspective of how the theory and practice of regulation.

The target of the research is to formulate theories, methodology and practical recommendations that will comprehensively evaluate the impact of external and internal factors of sustainable financial condition of the enterprise with the help of modeling financial indicators for the operational management of the finances of enterprise.

The research is based on the modern approaches of financial management and the provisions of microeconomics.

\section{Theory}

The main purpose of any kind of financial analysis is the assessment and identification of the internal problems of the enterprise for training, study and adoption of various management decisions, including the development, out of the crisis, the transition to bankruptcy procedures, purchase and sale of businesses, attracting investment (leverage).

Operational aspects of financial analysis are shown in the monitoring of the status of receivables and payables, justifying the most rational forms of payments to contractors, maintaining a balance between the inflow and outflow of funds from the financial results necessary for the daily settlement, monitoring indicators, the analysis of financial budgets and evaluation of their performance that expressed in the monitoring of the level of financial indicators characterizing the company's solvency.

The financial condition of the business entity characterized placement and use of resources (assets) and sources of their formation (equity and liabilities, mean liabilities). The main factors determining the financial condition, are, firstly, the implementation of the financial plan and updating as the need arises own working capital at the expense of profits and, secondly, the rate of turnover of working capital (assets). Signal indicator, which manifests the financial condition, solvency advocates.

Financial condition is characterized by a set of indicators that reflect the process of formation and use of its funds. In a market economy, the financial condition of the organization reflects the final results of its operations. 
Analyzing the above definitions of financial condition, can conclude that the financial condition characterized by a set of financial indicators and is the result of the circulation of capital, or the movement of assets and sources of their formation.

Furthermore, in our opinion, this concept needs to be supplemented in the general definition, namely, financial condition - is the level of financial support from enterprises and their sources.

Thus, the stability and the stability of the financial condition of the commercial organization depend on the results of industrial, commercial and financial activities. If the operational and financial plans are successfully carried out, it has a positive effect on the financial condition of the organization.

\section{Results}

Methodology consistent identifying and resolving problems in the financial condition of the operational aspects based on the results of the financial factor analysis, was created in the process of studying the financial and economic activities of industrial enterprises.

In Figure 1, there are presented a methodology of modeling the system of financial indicators.

To determine the key financial indicators in step 1a (figure 1) must diagnose financial condition. It was concluded that, in the main, many manufacturing companies have similar problems in the financial and economic activity and the basis of the methodology is necessary to lay the following tasks:

- low paying - from enterprises do not have enough cash to meet its obligations;

- low level of profit;

- low financial stability - a large proportion of the receivable.

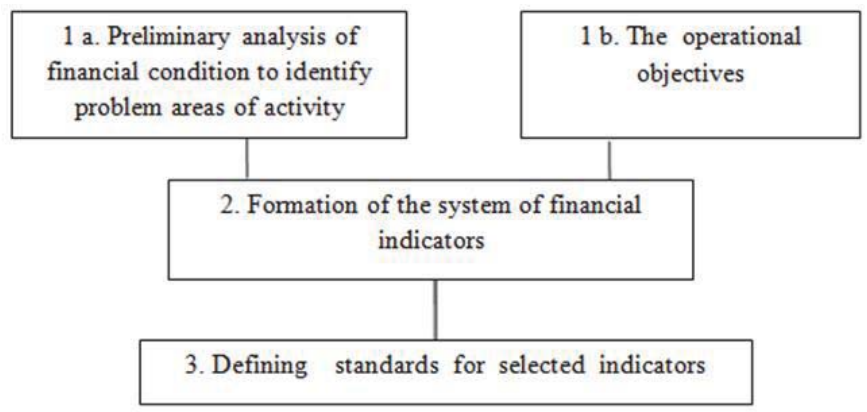

Fig. 1. Schematic of the formation of the system of financial indicators

The specifics of the production orientation requires constantly have sufficient liquid assets where there is the need to monitor the solvency of the organization. A lack of coverage in the most liquid and less liquid assets payables shows that organizations need to regulate the flow of money and the value of liabilities. Based on these results it is advisable to analyze the financial performance related to accounts receivable and payable, balance cash flow, sales profit from the financial information for the last 3 years.

Further, the next step $1 \mathrm{~b}$ (fig. 1), where the use of such goals as «balanced ratio of receivables and payables, cash flow and obtain the planned sales profit» for the enterprise will identify indicators that will provide operational management of the financial and economic activities of the entity.

The optimal number of indicators will reduce the amount of redundant information and will largely determine the quality of the analysis and management decisions. Endless modeling parameters, their excessive detail, endowing indicators are not their usual characteristics, expansion of management information leads to an increase in the cost of collecting and processing information, its redundancy and inefficient use.

Thus, developed system of financial performance, which will assess, analyze, plan and monitor the financial condition of the enterprise in the operational aspects.

The first indicator represents $\mathrm{R} 0$, the ratio of total cash balance at the beginning of the period and the cash inflow to outflow of funds (1).

$R 0=\frac{S D C+D S D}{D S D o}(1)$

where DSDo - cash outflow funds; 
SDS - in cash at the beginning of the period;

DSD - cash inflow funds.

The ratio of this indicator, many Russian economists recommend the use of 1 or more, which shows the solvency of a commercial organization.

The next indicator is calculated as the ratio $\mathrm{R} 1$ received cash for accrued revenue (2):

$R 1=\frac{S D C+D S D}{B}(2)$

where SDS - in cash at the beginning of the period;

DSD - cash inflow funds;

$B$ - revenue.

We believe that the rate of this index should be greater than 1 . This is due to the logic of the comparison is actually coming earnings (cash flow) with accrued. The company should receive a timely refund on investment in production working capital.

The second indicator is calculated as the ratio of $\mathrm{R} 2$ to cost of revenue (3):

$R 2=\frac{B}{C}(3)$

where $\mathrm{C}$ - cost;

$\mathrm{B}$ - revenue.

The increase of this index indicates increasing the efficiency of the company. It is believed that the specification should be set greater than 1.25, which is associated with the need to ensure a higher return (in particular due to inflation). Mortgaging the following condition: revenue $-100 \%$, cost (fixed and variable costs) $-80 \%$ profit on sales $-20 \%$. Return on sales is planned to 0.2 , profit from sales in the revenue should be $20 \%$. Product profitability as the ratio of profit to the cost, the norm is set $0.25=0.2$ / 0.8. Norm operational indicators K2 is calculate: 1 / $0.8=1.25$. Check the correctness of these regulations (4):

$$
\begin{aligned}
& P C=\frac{B}{C} \times \frac{P}{B}=\frac{P}{C}(4) \\
& \text { where } \mathrm{PC}-\text { profitability; } \\
& \mathrm{P} \text { - profit; } \\
& \mathrm{C} \text { - cost; } \\
& \mathrm{B}-\text { revenue. } \\
& \text { Mean, } 1.25 * 0.2=0.25 \text { (4). }
\end{aligned}
$$

For enterprise, in our opinion, it is appropriate to set the following rates of return of economic activity (table 1).

Table 1: Standards of profitability for enterprise

\begin{tabular}{|l|c|}
\hline Indicator & The norm \\
\hline Profitability of sales & 0,2 \\
\hline Profitability & 0,25 \\
\hline Operational indicator & 1,25 \\
\hline
\end{tabular}

Monitoring indicators outlined above will give the opportunity to achieve the planned level of profit and a certain level of cost for expanding the activities and achievements of the operational objective - development and effectiveness the company.

Based on the above parameters R1 and R2, R3 develop indicators (balance index funds), reflecting the influx of cash allocated to cover the cost, mean, balance spent money and working capital for production (5).

$$
R 3=\frac{S D C+D S D}{C}(5)
$$

where SDS - in cash at the beginning of the period;

DSD - cash inflow funds;

C - cost.

The author believes that the norm the index R3 should equal more than 1.25 .

To control the amount of accumulated earnings and cash outflows calculated indicator R4 (rate of collection of revenue), which indicates the need for additional financing of working capital. Calculate the indicator R4 (6).

$R 4=\frac{D S D o}{B}(6)$

where DSDo - cash outflow funds;

$B$ - revenue. 
By calculation derive the norm indicator R4: $1-1,25$.

Cost of products should be commensurate with the money spent on its release in the same period. For this indicator is calculated as the ratio of the cost of R5 in a cash outflow (7).

$R 5=\frac{C}{D S D o}(7)$

where DSDo - cash outflow funds;

$C$ - cost.

The ratio is established by dividing the index ratios $\mathrm{R} 0$ to $\mathrm{R} 3$, mean is less than 1 .

For the analysis necessary to establish the relationship of these indicators. Figure 2 shows the first block factor model developed indicators.

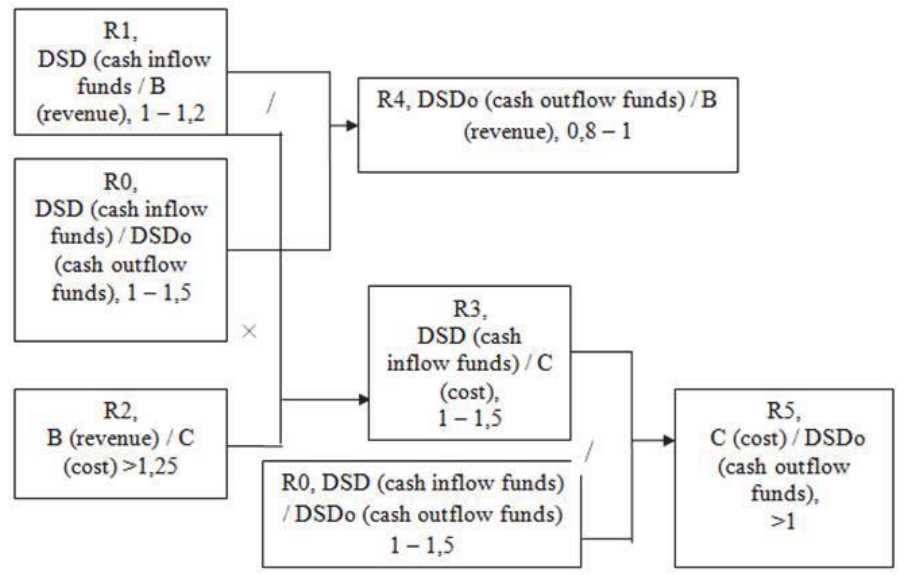

Fig. 2. Factor model of financial indicators

Thus, it can be argued that the following inequalities must be met:

$B \leq D S D \geq C(8)$

$\mathrm{B} \geq \mathrm{DSD} 0 \leq \mathrm{C}(9)$

where DSDo - cash outflow funds;

DSD - cash inflow funds;

$B$ - revenue.

$\mathrm{C}-$ cost.

Cash flow should be more than the revenue accrued through the timely collection of receivables and accrued cost more. Regarding cash outflows: cost should be less than the outflow, and more revenue, which in turn balances the inflow and outflow.

The next block of indicators aimed at regulating the payables and receivables relative to revenue and cost, mean, business activities of enterprises.

Consider the indicator of raising funds, showing the share payable in cash outflow, indicating the amount of money the organization of the output of a turn (10).

Indicator raise money $=\frac{\mathrm{KZ}}{\mathrm{DSDo}}(10)$

where KZ - balance payable;

DSDo - cash outflow funds.

The ratio of this index derive by calculation, namely the ratio of accounts payable to multiply the ratio of revenue and cash outflows, we obtain the rate equal to $0.2-0.25$. 11).

We propose to calculate the indicator diversion of funds characterizing coating receivables cash inflow (formula

Indicator diversion of funds $=\frac{\mathrm{DSD}}{\mathrm{DZ}}(11)$

where DSD - cash inflow funds;

$\mathrm{DZ}$ - debtors.

It is the norm is $0.2-0.25$ (receivables to the cost / inflow to the cost of $=0.25 / 1.25=0.2$ ).

To find out how much money from the profit goes to the repayment of debt, consider the indicator cover arrived 
(formula 12).

Indicator coverage of profit $=\frac{\mathrm{KZ}}{\mathrm{P}}(12)$

Where KZ - balance payable;

$\mathrm{P}-$ profit.

The ratio of the above figure derive by calculation: cost to payables divided into operational indicator (formula 3), we obtain $\leq 1$.

This figure should be viewed in relation to the measure of the proportion of receivables in profit (formula 13).

Indicator diversion of profit $=\frac{\mathrm{DZ}}{\mathrm{P}}(13)$

where DZ - debtors;

$P-$ profit.

The ratio index derived by calculation and amounts to 1 .

These figures show an increase and a decrease in financial risk, mean, excess rate of receivables and payables in profit constitutes a violation of their relative balance of revenue and product costs. Factor model of these indicators is presented in Figure 3.

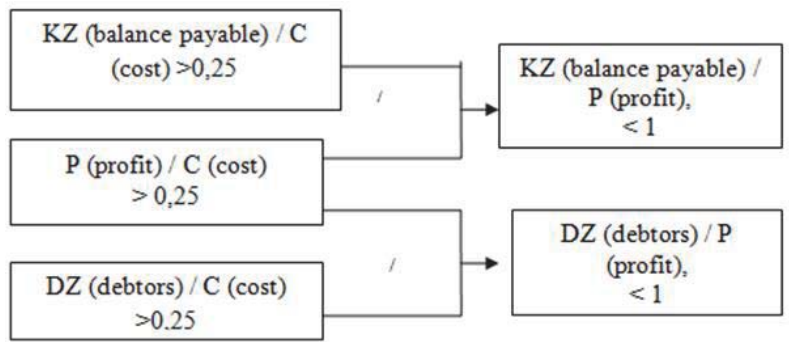

Fig. 3. Factor model indicators of coverage of profit and diversion of profit

\section{Conclusions}

Key suggestions for further development of procedures for the final modeling of financial indicators for the analysis of financial condition are:

1) the calculation of own standards or optimal levels of financial ratios for the analyzed enterprise using instructional techniques (for example, the optimal level of current ratio is determined from the ratio of the amounts of receivables and payables, current assets, return on sales, the timing and rhythm of the receipt of funds buyers the timing and rhythm of repayment of debts to suppliers and other creditors, the turnover of receivables and payables);

2) isolation of a narrow "indicator" sample financial ratios, the composition of which may vary for different enterprises;

3) qualitative evaluation of test performance, based on a comparison with the calculated optimum level, trends change, mutual comparison and logical rules adopted;

4) development of a model format of the conclusion of the financial performance, which is not just stating the problems analyzed the enterprise, but also indicate factors and future change, and to make recommendations for overcoming them, mitigation or enhancement.

Thus, the analysis and assessment of the financial condition of the company on the basis of financial indicators developed will allow business entities comprehensively characterize the condition and cash requirements and predict financial strategy in terms of economic instability.

\section{References}

Audretsch, D.B., Lehmann, E.E. Corporate governance and entrepreneurial firms// Foundations and Trends in Entrepreneurship, 2014, 10 (1-2), pp. 1-160.

Basak, S., Makarov, D. Strategic Asset Allocation in Money Management// Journal of Finance, 69 (1), 2014, pp. 179-217.

Bradley, D., Clarke, J., Lee, S., Ornthanalai. Are analysts' recommendations informative? Intraday evidence on the impact of time stamp delays// Journal of Finance, 69 (2), 2014, pp. 645-673. 
Gordon J. Alexander, Alexandre M. Baptista. Stress testing by financial intermediaries: Implications for portfolio selection and asset pricing// Journal of Financial Intermediation, Volume 18, Issue 1, pp. 65-92 (January 2009).

Daniel Bradley, Xi Liu and Christos Pantzalis. Bucking the Trend: The Informativeness of Analyst Contrarian Recommendations/l Financial Management, Summer 2014, Volume 43, Issue 2, pp. 391-414.

Dimitratos, P., Liouka, I., Young, S. A missing operationalization: Entrepreneurial competencies in multinational enterprise subsidiaries/l Long Range Planning, 47 (1-2), 2014, pp. 64-75.

Javeria Farooqi, Oneil Harris, Thanh Ngo. Corporate diversification, real activities manipulation, and firm value// Journal of Multinational Financial Management, Volume 27, pp. 130-151, (October 2014).

Leary, M.T., Roberts, M.R. Do Peer Firms Affect Corporate Financial Policy/l Journal of Finance, 69 (1), pp. 139-178.

Seal, W., Mattimoe, R. Controlling strategy through dialectical management// Management Accounting Research, 2014,25 (3), pp. 230 246.

Sysoyeva, L., Buriak, A. Development prerequisites for the regulatory approaches of the systemic risk regulation in finances//Source of the Document Economic Annals-XXI, 1-2 (2), 2014, pp. 20-23.

Yongtao Hong, Fariz Huseynov and Wei Zhang. Earnings Management and Analyst Following: A Simultaneous Equations Analysis//Financial Management, Summer 2014, Volume 43, Issue 2, pp. 355-390.

Adigamova Farida F., Safiullin Marat A., Tufetulov Aidar M. Mechanism of state tax regulation in the global economy // Mediterranean Journal of Social Sciences vol. 5 № 24, November 2014, pp. 193-199

Valitov, S.M., Sirazetdinova, A.Z. (2014). Project risks' management model on an industrial entreprise. Asian Social Science, 10 (21), pp. 242-249. 